\title{
Tindakan pencegahan infeksi silang kepaniteraan klinik mahasiswa di RSGM Universitas Prima Indonesia
}

\author{
Yohannes Stephen Brilliant Hutajulu, Mangatas Halomoan Parluhutan Hutagalung, Molek \\ Fakultas Kedokteran Gigi Universitas Prima Indonesia
}

*Korespondensi: yohaneshutajulu@gmail.com

DOI: $10.34012 /$ jpms.v3i1.1671

C 2021 JPMS. All rights reserved

\begin{abstract}
Abstrak
Banyak tenaga medis dan pasien di kedokteran gigi yang beresiko tertular penyakit infeksi. Dokter gigi muda rentan mengalami infeksi silang selama memberikan perawatan pada pasien. Penelitian ini bertujuan untuk menganalisis tingkat pengetahuan dan tindakan pencegahan infeksi silang kepaniteraan klinik RSGM Universitas Prima Indonesia. Penelitian ini merupakan survei analitik dengan desain cross sectional yang bertujuan untuk mengetahui gambaran pengetahuan dan tindakan pencegahan infeksi silang kepanite-raan klinik RSGM Universitas Prima Indonesia. Penelitian dilakukan di RSGM Universitas Prima Indonesia pada bulan Maret 2021. Populasi dalam penelitian ini adalah seluruh mahasiswa kepaniteraan klinik RSGM FKG Universitas Prima Indonesia yaitu sebanyak 100 orang. Dari hasil perhitungan sampel dengan menggunakan rumus Slovin maka sampel yang digunakan dalam penelitian ini berjumlah 80 orang. Berdasarkan hasil penelitian dan pembahasan, maka dapat ditarik kesimpulan bahwa mayoritas mahasiswa kepaniteraan klinik RSGM Universitas Prima Indonesia pengetahuan dan tindakan pencegahan infeksi silang berturut-turut pada kategori baik (95\%) dan kategori cukup (80\%).
\end{abstract}

Kata kunci: Pengetahuan, tindakan pencegahan, infeksi silang, kepaniteraan

\begin{abstract}
Many medical personnel and patients in dentistry are at risk of contracting infectious diseases. Young dentists are prone to cross-infection while providing care to patients. This study aims to analyze the level of knowledge and preventive measures for cross infection in the secretariat of the clinic at the Prima Indonesia University Dental Hospital. This study is an analytical survey with a cross sectional design which aims to describe the knowledge and measures to prevent cross infection in the clinic at the Prima Indonesia University Dental Hospital. The study was conducted at the Prima Indonesia University Dental Hospital in March 2021. The population in this study were all students of the clinical secretariat of the Universitas Prima Indonesia Dental Hospital, namely 100 people. From the calculation of the sample using the Slovin formula, the sample used in this study amounted to 80 people. Based on the results of the research and discussion, it can be concluded that the majority of the clinical clerkship students of the Prima Indonesia University Hospital for knowledge and crossinfection prevention measures are in the good category (95\%) and the moderate category (80\%), respectively.
\end{abstract}

Keywords: Knowledge, preventive measures, cross infection, secretariat

\section{Pendahuluan}

Kedokteran gigi merupakan salah satu bidang yang rawan untuk terjadinya kontaminasi silang antara pasien-dokter gigi, pasienperawat dan pasien-pasien. ${ }^{1}$ Banyak sumber penularan infeksi pada praktek dokter gigi antara lain tangan, saliva, debu/partikel pengeburan gigi, darah, udara, pakaian, air, aerosol, percikan atau tetesan, plak, kalkulus, bahan tumpatan gigi dan debris dari rongga mulut atau luka terbuka dapat juga menjadi sumber infeksi atau kontaminasi. Sebab itu, perlengkapan praktek dan instrumen harus dijaga kebersihannya dan sterilisasi untuk mencegah terjadinya infeksi. $^{2}$

Hasil penelitian menunjukkan hanya $43,8 \%$ dokter gigi yang menggunakan kaca mata pelindung, 62,5\% yang menggunakan masker pada saat memeriksa pasien, 56,3\% dokter gigi yang melakukan pergantian sarung tangan setiap pasien baru dan $75 \%$ dokter gigi mencuci tangan sebelum dan sesudah perawatan. Kaca 
mata pelindung dan masker 95\% dapat melindungi dokter gigi dari droplet yang telah terkontaminasi penyakit, kurangnya kenyamanan dalam pemakaian dan mahalnya harga kaca mata pelindung menyebabkan dokter gigi tidak menggunakannya selama prosedur perawatan. ${ }^{3}$

Banyak tenaga medis dan pasien di kedokteran gigi yang beresiko tertular mikroorganisme pathogen seperti Virus Hepatitis B (VHB), Virus Hepatits C (VHC), Human Immunodeficiency Virus (HIV), Microbacterium tuberculosis, Virus Herpes Simples (VHS), Virus Influenza (H1N1), Staphylococcus, Streptococcus, serta berbagai macam bakteri dan virus lainnya. ${ }^{4}$ Menurut WHO, di antara 35 juta pekerja kesehatan di seluruh dunia, sekitar tiga juta terkontaminasi oleh patogen melalui darah setiap tahun. Dua juta di antaranya tertular VHB, 900.000 pekerja tertular virus Hepatitis C (VHC) dan 170.000 pekerja tertular HIV. ${ }^{3}$

Hepatitis B adalah salah satu penyakit yang paling umum dan serius di dunia. Penyakit ini adalah 100 kali lebih menular dibandingkan Human Immunodeficiency Virus (HIV). Menurut WHO, ada sekitar 350 juta pembawa Virus Hepatitis $B$ (VHB) di seluruh dunia. Sampai dengan 2 juta orang meninggal setiap tahun dari infeksi Virus Hepatitis $B$ (VHB), sehingga menjadi urutan kesembilan penyebab utama kematian di seluruh dunia. Penelitian yang dilakukan oleh American Dental Association (ADA) menunjukkan bahwa penularan penyakit hepatitis B terhadap tenaga kesehatan khususnya dokter gigi yang tidak diimunisasi mempunyai risiko enam kali lebih besar dari populasi umum di Amerika Serikat yaitu sebesar $76 \%$. Hal inilah yang menyebabkan tenaga medis, khususnya dokter gigi harus memperhatikan keselamatan dirinya dengan cara menerapkan proteksi diri sebagai upaya untuk mencegah terjadinya infeksi silang. ${ }^{5}$

Saat ini masih banyak dari tenaga kesehatan yang masih kurang memperhatikan tentang pentingnya mencegah terjadinya infeksi silang yang mungkin bisa saja setiap saat dapat dialami oleh petugas kesehatan. Hal ini yang perlu menjadi perhatian dari setiap petugas kesehatan agar selalu menjaga diri dengan cara mengetahui bagaimana cara pencegahan terjadinya infeksi silang. ${ }^{6}$

Faktor-faktor yang berpengaruh terhadap pencegahan penyakit adalah pengetahuan, sikap dan tindakan seseorang terhadap penyakit tersebut. Seseorang yang memiliki pengetahuan yang baik mengenai suatu hal cenderung akan mengambil keputusan yang lebih tepat berkaitan dengan masalah. Pengetahuan dan sikap merupakan respon seseorang terhadap stimulus atau rangsangan yang masih bersifat terselubung dan masih terbatas pada perhatian, persepsi, kesadaran. Sedangkan tindakan merupakan respon terhadap stimulus atau rangsangan yang dapat diamati oleh orang lain. Jadi secara teori pengetahuan seseorang akan mempengaruhi sikap dan sikap tersebut teraplikasi dalam suatu tindakan seseorang. ${ }^{7}$

Penelitian Hanafiah et al. (2016) menunjukkan sebanyak $48,75 \%$ mahasiswa berpengetahuan cukup, sedangkan sikap mahasiswa tergolong baik $55 \%$ dan perilaku mahasiswa cukup sebanyak 46,25\%. Dapat dilihat bahwa tingkat pengetahuan mahasiswa kepaniteraan dalam kategori cukup. Tingkat pengetahuan tentang pentingnya pencegahan terjadinya infeksi silang yang baik menjadi dasar dari tindakan apa yang harusnya nanti akan dilakukan untuk mencegah terjadinya infeksi silang. ${ }^{8}$

Prosedur penatalaksanaan infeksi silang yang umum digunakan adalah merujuk pada aturan yang dikeluarkan oleh Centre for Disease Control (CDC) yang disebut sebagai kewaspadaan universal (universal precaution). Kewaspadaan universal adalah bahwa semua darah dan cairan tubuh yang berada di lingkungan kerja harus dianggap sebagai bahan yang dapat menimbulkan infeksi. Bersama dengan American Dental Association (ADA), CDC menyusun tahapan kewaspadaan universal sebagai berikut: 1) perlindungan pribadi, 2) sterilisasi dan desinfeksi bahan atau alat serta daerah kerja dan desinfeksi permukaan di ruang praktek yang mungkin terciprati atau tersentuh bahan yang terkontaminasi, dan 3) pembuangan limbah yang benar. ${ }^{9}$

Dari wawancara terdahulu yang dilakukan pada pasien RSGM UNPRI didapati bahwa pasien menginginkan adanya prosedur penanganan pasien yang menderita infeksi silang ketika menangani atau melakukan perawatan gigi dan mulut. Dokter gigi muda sebagai seseorang yang tengah aktif menjalankan pendidikan klinik diberi kesempatan untuk 
terlibat dalam pelayanan kesehatan di bawah bimbingan dan pengawasan dosen atau supervisior. Dokter gigi muda dalam hal ini sebagai bagian dari tenaga kesehatan wajib menjaga keselamatan dirinya dan orang lain termasuk dalam hal pelaksanaan kontrol infeksi. Penelitian ini bertujuan untuk menganalisis tingkat pengetahuan dan tindakan pencegahan infeksi silang kepaniteraan klinik RSGM Universitas Prima Indonesia.

\section{Metode}

Penelitian ini merupakan survei analitik dengan desain cross sectional yang bertujuan untuk mengetahui gambaran pengetahuan dan tindakan pencegahan infeksi silang kepaniteraan klinik RSGM Universitas Prima Indonesia. Penelitian dilakukan di RSGM Universitas Prima Indonesia pada bulan Maret 2021. Populasi dalam penelitian ini adalah seluruh mahasiswa kepaniteraan klinik RSGM FKG Universitas Prima Indonesia yaitu sebanyak 100 orang. Dari hasil perhitungan sampel dengan menggunakan rumus Slovin maka sampel yang digunakan dalam penelitian ini berjumlah 80 orang.

\section{Hasil}

Berdasarkan data yang diperoleh dari hasil penelitian didapatkan distribusi karakteristik responden berdasarkan jenis kelamin, dan usia responden dapat dilihat pada tabel 3.1 Hasil penelitian didapatkan bahwa jenis kelamin responden yang laki-laki sebanyak 20 orang dengan persentase sebesar $25 \%$, jenis kelamin responden perempuan sebanyak 60 orang dengan persentase sebesar $75 \%$. Untuk usia responden, responden dengan usia 21-26 tahun sebanyak 72 orang dengan persentase $90 \%$, dan untuk usia $27-32$ tahun sebanyak 8 orang dengan persentase sebesar $10 \%$.

Tabel 1. Karakteristik responden $(n=80)$

\begin{tabular}{ccc}
\hline Karakteristik & Jumlah (n) & Persentase (\%) \\
\hline Jenis Kelamin & & \\
Laki-Laki & 20 & 25,0 \\
Perempuan & 60 & 75,0 \\
Usia & & \\
$21-26$ & 72 & 90,0 \\
$27-32$ & 8 & 10,0 \\
\hline
\end{tabular}

Pada tabel 2 dapat dilihat bahwa untuk nilai persentase kategori pengetahuan baik terhadap infeksi silang pada mahasiswa Kepaniteraan Klinik RSGM Universitas Prima Indonesia sebesar 95\% dan kategori pengetahuan cukup sebesar 5\%, untuk kategori tindakan pencegahan infeksi silang pada mahasiswa kepaniteraan klinik RSGM Universitas Prima Indonesia yang memiliki tindakan baik sebesar $80 \%$, dan yang memiliki tindakan cukup sebesar $20 \%$.

Tabel 2. Persentase Pengetahuan Tindakan Pencegahan Infeksi Silang

\begin{tabular}{lcc}
\hline Ketegori & Jumlah (n) & Persentase (\%) \\
\hline Pengetahuan & 76 & \\
Baik & 4 & 95,0 \\
Cukup & - & 5,0 \\
Kurang & & - \\
Tindakan & 64 & \\
Baik & 16 & 80,0 \\
Cukup & - & 20,0 \\
Kurang & & - \\
\hline
\end{tabular}

\section{Pembahasan}

Penelitian ini bertujuan untuk menganalisis tentang pengetahuan pada tindakan pencegahan infeksi silang kepaniteraan klinik mahasiswa RSGM Universitas Prima Indonesia. Dari hasil penelitian yang sudah dilakukan dengan sampel sebanyak 80 orang responden, dapat dilihat hasilnya bahwa untuk pengetahuan mahasiswa tentang infeksi silang masuk ke dalam kategori baik sebesar 95\% dan kategori cukup sebesar $5 \%$. Sedangkan untuk tindakan pencegahan infeksi silang pada mahasiswa kepaniteraan, 
persentase kategori tindakan baik sebesar $80 \%$, dan untuk tindakan dengan kategori cukup sebesar $20 \%$.

Penelitian ini sejalan dengan penelitian Noviyanti (2018) yang menunjukkan bahwa kepatuhan penerapan pencegahan dan pengendalian oleh mahasiswa profesi kedokteran gigi terhadap infeksi silang pada tindakan ekstraksi gigi di RSGM Unsyiah sebesar 78\% (kategori baik). ${ }^{10}$ Penelitian yang sama juga dilakukan Hanafiah (2016) tentang pengetahuan, sikap dan prilaku mahasiswa kepaniteraan klinik terhadap standard precautions di Rumah Sakit Gigi dan Mulut Pendidikan FKG USU Medan dan didapatkan hasil sebanyak $48,75 \%$ mahasiswa berpengetahuan cukup, sedangkan sikap mahasiswa tergolong baik $55 \%$ dan perilaku mahasiswa cukup sebanyak $46,25 \%$. Dengan tingkat pengetahuan yang masuk ke dalam kategori cukup, seharusnya untuk tingkat pengetahuan tentang pentingnya pencegahan terjadinya infeksi silang masuk ke dalam kategori baik, karena inilah yang menjadi dasar dari tindakan apa yang harusnya nanti akan dilakukan untuk mencegah terjadinya infeksi silang. ${ }^{8}$

Hasil penelitian ini berbeda dengan penelitian yang dilakukan Sari et al (2014), hasil penelitian menunjukkan bahwa ada sebanyak 69 orang $(86,3 \%)$ yang berpengetahuan tinggi melakukan penatalaksanaan pencegahan infeksi dengan baik, sedangkan yang rendah sebanyak 18 orang $(24,3 \%)$ yang melakukan penatalaksanaan pencegahan infeksi dengan tidak baik. ${ }^{11}$

Hal ini menjadi dasar kesimpulan bahwa semakin tinggi pengetahuan mahasiswa kepaniteraan klinik RSGM Universitas Prima Indonesia mengenai infeksi silang maka semakin tinggi juga tindakan pencegahan infeksi silang pada mahasiswa kepaniteraan klinik RSGM Universitas Prima Indonesia yang akan dilakukan.

Menurut Green (1980) perilaku manusia dalam hal kesehatan dipengaruhi oleh dua faktor pokok yaitu faktor perilaku (behavior causes) dan faktor di luar perilaku (non-behavior causes). Perilaku itu sendiri ditentukan atau terbentuk dari tiga faktor yaitu: 1) faktor-faktor predisposisi (predisposing factors), yang terwujud dalam pengetahuan, sikap, kepercayaan, keyakinan dan nilai-nilai; 2) faktor-faktor pendukung (enabling factors), yang terwujud dalam lingkungan fisik, tersedia atau tidak tersedianya fasilitas-fasilitas atau sarana-sarana kesehatan. Misalnya puskesmas, obat-obatan, alat-alat kontrasepsi, jamban dan sebagainya; dan 3) faktor-faktor pendorong (reinforching factor), yang terwujud dalam sikap dan perilaku petugas kesehatan atau petugas lainnya yang merupakan kelompok referensi dari perilaku masyarakat. ${ }^{12}$

American Dental Association (ADA) merekomendasikan bahwa setiap pasien harus dianggap berpotensi menular dan standar precautions harus diterapkan bagi semua pasien. Hal ini bertujuan untuk mengurangi dan mencegah infeksi iatrogenik dan nosokomial. Dokter gigi dan staf harus melindungi diri dengan mengikuti program imunisasi yang rutin. Standard precaution terdiri dari dua yaitu standar tindakan pencegahan dan transmission based precaution yaitu standar tindakan pencegahan yang diaplikasikan terhadap semua pasien dirancang untuk mereduksi resiko transmisi mikroorganisme dari sumber infeksi yang diketahui dan tidak diketahui seperti darah, cairan tubuh, ekskresi dan sekresi. ${ }^{13}$

\section{Kesimpulan}

Berdasarkan hasil penelitian dan pembahasan, maka dapat ditarik kesimpulan bahwa mayoritas mahasiswa kepaniteraan klinik RSGM Universitas Prima Indonesia pengetahuan dan tindakan pencegahan infeksi silang berturut-turut pada kategori baik (95\%) dan kategori cukup (80\%).

\section{Referensi}

1. Pratanjana GP. 2020. Penerapan Proteksi Diri Dokter Gigi Sebagai Upaya Pencegahan Terhadap Infeksi Silang Penyakit Menular. Institut Ilmu Kesehatan Strada Kediri.

2. Sarwono AP. 2019. Gambaran Pelaksanaan Standar Operasional Prosedur Pengendalian Infeksi Oleh Mahasiswa Profesi Di RSGM FKG Usakti Jakarta. Jurnal PENA Vol.33 No.2

3. Wibowo T, Parisihni K, Haryanto D. 2009. Proteksi Dokter Gigi Sebagai Pemutus Rantai Infeksi Silang. Jurnal PDGI Vol. 58 No.2: 6-9

4. Siampa FA, Samad R. 2014. Penerapan proteksi dokter gigi sebagai upaya pencegahan terhadap infeksi silang: 
Penelitian di Kota Makassar. Makassar Dental Journal Vol. 3 No. 1

5. Suleh MM, Wowor VNS, Mintjelungan CN. 2015. Pencegahan dan Pengendalian Infeksi Silang Pada Tindakan Ekstraksi Gigi di Rumah Sakit Gigi Dan Mulut PSPDG FK UNSRAT. Jurnal e-GiGi (eG) Vol. 3 No. 2

6. Estri BA, Putri IM, Rosida L, Endriyani A. 2019. Pengendalian dan Pencegahan Infeksi (PPI). Universitas 'Aisyiyah Yogyakarta.

7. Notoatmodjo S. 2014. IImu Perilaku Kesehatan. Jakarta: Rineka Cipta.

8. Hanafiah OA, Yanti GN, Faradilla C, Wulandari D. 2016. Tingkat Pengetahuan Mahasiswa Kepaniteraan Klinik FKG USU Tentang Standard Precautions Pada Pasien Setelah Tindakan Perawatan Gigi di RSGMP FKG USU. dentika Dental Journal Vol. 19 No. 1: 4-11

9. Doni LB, Debbie SR. 2012. Modern dental assisting. Edisi 10. Canada: Elsevier Saunders

10. Noviyanti L. 2018. Gambaran Tingkat Kepatuhan Penerapan Pencegahan dan Pengendalian Infeksi Silang Pada Tindakan Ekstraksi Gigi (Kajian Pada Mahasiswa Profesi Kedokteran Gigi dan Mulut (RSGM) Unsyiah). Fakultas Kedokteran Gigi Universitas Syiah Kuala

11. Sari IP, Afriza D, Rosenoer M. 2014. Hubungan Antara Pengetahuan Tentang Infeksi Silang Dengan Penatalaksanaan Pencegahan Infeksi. B-Dent: Jurnal Kedokteran Gigi Universitas Baiturrahmah Vol. 1 No. 1

12. Green LW, Kreuter MW. 2005. Health Program Planning: An Educational and Ecological Approach. Fourth Edition. New York: McGraw-Hill

13. The Dental Council. 2005. Code of practice relating to infection control in dentistry. 57 Merrioj Square Dublin 2 